\title{
Ryhmäkoon ja eläintiheyden vaikutus kasvavien lihanautojen tuotantoon ja hyvinvointiin
}

\author{
Leena Tuomisto $^{1)}$, Arto Huuskonen ${ }^{1)}$, Jaakko Mononen ${ }^{2)}$, Risto Kauppinen ${ }^{3)}$, Leena Ahola ${ }^{2)}$ ja Paula \\ Martiskainen $^{2)}$ \\ ${ }^{1)}$ Maa- ja elintarviketalouden tutkimuskeskus, Pohjois-Pohjanmaan tutkimusasema, Tutkimusaseman- \\ tie 15,92400 Ruukki.etunimi.sukunimi@mtt.fi \\ ${ }^{2)}$ Kuopion yliopisto, Soveltavan biotekniikan instituutti, PL 1627, 70211 Kuopio. etuni- \\ mi.sukunimi@uku.fi \\ ${ }^{3)}$ Savonia-ammattikorkeakoulu, Maaseutuala, PL 72, 74101 Iisalmi.risto.kauppinen@savonia-amk.fi
}

\section{Tiivistelmä}

Tämän kirjallisuuskatsauksen tarkoituksena oli selvittää, miten ryhmäkoko ja eläintiheys vaikuttavat kasvavien lihanautojen tuotantoon ja hyvinvointiin. Suhteellisen pieni ryhmäkoko (noin 5-20 eläintä) on turvallinen valinta nautojen tuotannon kannalta. Nautojen kasvu saattaa heiketä ryhmäkoon kasvaessa (20-60 eläintä), mutta suurien ryhmäkokojen osalta kaivataan lisätutkimuksia. Nautojen sosiaalisen käyttäytymisen perusteella pieni ryhmäkoko on suurta suositeltavampi. Pienessä ryhmässä eläinten on helpompi tunnistaa toisensa yksilöllisesti ja muistaa oma asemansa lauman hierarkiassa suhteessa muiden laumanjäsenten asemaan kuin suuremmassa ryhmässä. Ryhmäkoon ylärajana voidaan pitää 50-70 eläintä, jonka ylittyessä naudan kyky tunnistaa toisia yksilöitä heikkenee. Jos lihanautoja pidetään suurissa ryhmissä, tilaa on oltava runsaasti, jotta eläimet voivat halutessaan muodostaa pienempiä alaryhmiä.

Eläintiheyden kasvaessa lihanautojen kasvu, rehunkulutus ja rehuhyötysuhde heikkenevät, mutta eläintiheydellä ei ole havaittu vaikutusta ruhon tai lihan laatuun. Eläintiheyden kasvu heikentää lihanautojen terveyttä lisäämällä häntäpolkemia. Lisäksi lisämunuaisten toiminta voi muuttua, minkä voidaan katsoa johtuvan kroonisesta stressistä. Eläintiheyden kasvaessa lihanaudat myös likaantuvat herkemmin. Eläintiheyden kasvulla on monia negatiivisia vaikutuksia lihanautojen käyttäytymiseen. Karsinatilan pienentyessä vasikoiden leikkikäyttäytyminen vähenee. Makuutilan vähentyessä ryhmän makuukäyttäytyminen muuttuu epäsynkronisemmaksi ja makaavien eläinten häirintä voi lisääntyä. Hyvin korkeassa eläintiheydessä eläinten makuulla viettämä aika vähenee. Eläintiheyden kasvaessa nojailukäyttäytyminen voi lisääntyä. Rakolattialla karsinan ahtaus vaikeuttaa makuulle asettumista ja ylösnousua, minkä vuoksi epänormaalisti suoritetut liikkeet lisääntyvät. Korkeassa eläintiheydessä eläimillä voi olla vaikeuksia haluamansa yksilötilan säilyttämisessä tai dominoivan lajikumppanin väistämisessä, mikä lisää eläinten välisiä aggressioita.

Tutkimustuloksien perusteella Suomen eläinsuojelusäädöksissä esitetyt ryhmäkasvatettavien nautojen vähimmäistilasuositukset $\left(1,8-4,0 \mathrm{~m}^{2} /\right.$ eläin eläinten koosta ja karsinatyypistä riippuen) ovat lihanautojen kasvatuksessa ehdoton eläintiheysminimi. Jotta naudoilla olisi mahdollisuus toteuttaa paremmin lajintyypillistä käyttäytymistään, tilaa eläintä kohden tulisi olla suosituksiakin enemmän. Etenkin rakolattiakasvatuksessa lisätila parantaisi eläinten terveyttä ja voisi vaikuttaa myönteisesti myös eläinten kasvuun. Suosituksissa kaikille yli $500 \mathrm{~kg}: \mathrm{n}$ painoisille lihanaudoille on annettu sama minimitila, mutta on selvää, että yli $600 \mathrm{~kg}: \mathrm{n}$ painoinen eläin tarvitsee enemmän tilaa kuin $500 \mathrm{~kg}: \mathrm{n}$ painoinen eläin. Siten varsinkin kasvatuksen loppuvaiheessa naudoilla tulisi olla käytössään vähimmäistilasuosituksiakin suurempi karsinatila.

Asiasanat: kotieläintuotanto, lihakarja, tuotantoympäristö, naudanlihantuotanto, ryhmäkasvatus, käyttäytyminen, hyvinvointi, ryhmäkoko, eläintiheys 


\section{Johdanto}

Lihanautojen ryhmäkasvatus on vallitseva käytäntö naudanlihantuotannossa. Tämän kirjallisuuskatsauksen tavoitteena oli selvittää, miten eläinryhmän koko ja eläintiheys vaikuttavat kasvavien lihanautojen tuotantoon ja hyvinvointiin.

\section{Ryhmäkokoa ja eläintiheyttä koskevat eläinsuojelusäädökset}

Suomen eläinsuojelusäädösten mukaan yli kahdeksan viikon ikäistä vasikkaa ei saa kasvattaa yksittäiskarsinassa (MMMA 7.6.1996/396). Yli kuuden kuukauden ikäisten sonnien ryhmäkoon suuruudeksi suositellaan korkeintaan 20 eläintä (MMMA 3.6.2002/6/EEO/2002). Kaikkien eläinten, mukaan lukien naudan, tilantarpeesta on eläinsuojeluasetuksessa (MMMA 7.6.1996/396) määrätty: "Pitopaikan tulee olla kunkin eläinlajin erityistarpeet huomioon ottaen riittävän tilava. Eläimen on voitava pitopaikassaan seistä ja levätä luonnollisessa asennossa sekä liikkua. Eläimen tulee voida pitopaikassaan nousta makuulta luonnollisella tavalla. Samassa pitopaikassa pidettävien eläinten tulee voida pitopaikassaan asettua yhtäaikaa makuulle”. Lisäksi eläinsuojelusäädöksissä on esitetty tarkentavia vähimmäistilavaatimuksia vasikoille (Taulukko 1) ja vähimmäistilasuosituksia yli kuuden kuukauden ikäisille naudoille (Taulukko 2).

Taulukko 1. Vasikoiden (ikä alle 6 kuukautta) vähimmäistilavaatimukset ryhmäkasvatuksessa (MMMp 23.5.1997/14/EEO/1997).

\begin{tabular}{cc}
\hline Vasikan paino $(\mathrm{kg})$ & Karsina $\left(\mathrm{m}^{2} /\right.$ eläin $)$ \\
\hline Alle 150 & 1,5 \\
$150-220$ & 1,7 \\
yli 220 & 1,8 \\
\hline
\end{tabular}

Taulukko 2. Yli kuuden kuukauden ikäisten lihanautojen vähimmäistilasuositukset ryhmäkasvatuksessa (MMMp 23.5.1997/14/EEO/1997).

\begin{tabular}{cccc}
\hline $\begin{array}{c}\text { Lihanauta } \\
\text { ikä }(\mathrm{kk})\end{array}$ & $\begin{array}{c}\text { Naudan keskimääräinen } \\
\text { paino }(\mathrm{kg})\end{array}$ & $\begin{array}{c}\text { Rakolattiakarsina } \\
\left(\mathrm{m}^{2} / \mathrm{eläin}\right)\end{array}$ & $\begin{array}{c}\text { Kiinteäpohjainen karsina } \\
\left(\mathrm{m}^{2} / \mathrm{eläin}\right)\end{array}$ \\
\hline $6-9$ & $200-300$ & 1,8 & 2,5 \\
$9-13$ & $300-400$ & 2,0 & 3,0 \\
$13-15$ & $400-500$ & 2,3 & 3,5 \\
Yli 15 & Yli 500 & 2,5 & 4,0 \\
\hline
\end{tabular}

\section{Ryhmäkoon vaikutus tuotantoon}

Nuorilla eläimillä tehdyissä tutkimuksissa ryhmäkoolla ei ole todettu vaikutusta vasikoiden kasvuun (Hristov 1974, Von Shlichting ym. 1990). Hristovin (1974) kokeessa ryhmäkoko oli 6, 10 tai 20 vasikkaa ja Von Shlichtingin ym. (1990) kokeessa 5 tai 10 vasikkaa. Muutamissa tutkimuksissa vanhemmilla eläimillä ryhmäkoon suureneminen on heikentänyt eläinten kasvua. Neumannin ym. (1974) tutkimuksessa 10 eläimen sonniryhmä kasvoi paremmin kuin 20 eläimen ryhmä, joka puolestaan kasvoi paremmin kuin 40 eläimen ryhmä. Plyaschenkon ja Yakovlevin (1987) kokeessa sonnit kasvoivat paremmin 20 ja 30 eläimen ryhmissä kuin 40 eläimen ryhmässä. MacNeil ym. (1989) tutkivat sonnien kasvua feedlot-oloissa. Ensimmäisessä kokeessa sonnit kasvoivat paremmin ja niiden ihonalainen rasvakerros oli paksumpi 30 kuin 60 eläimen ryhmässä, kun taas toisessa kokeessa ryhmän koolla (34 tai 68 sonnia) ei ollut vaikutusta eläinten kasvuun tai rasvoittumiseen. Hindhede ym. (1996) eivät havainneet ryhmäkoolla (6 tai 12 eläintä) vaikutusta hiehojen kasvuun, rehunkulutukseen tai rehuhyötysuhteeseen.

\section{Ryhmäkoon vaikutus käyttäytymiseen}

Ryhmäkoko vaikuttaa nautaryhmän dominanssihierarkian vakauteen ja sitä kautta ryhmässä esiintyvien aggressioiden määrään. Pysyvässä ryhmässä nautojen väliset suhteet ovat vakaita, jolloin toistuvia 
välienselvittelyjä ei tarvita (Hafez ja Bouissou 1975). Tämä kuitenkin edellyttää, että naudat pystyvät tunnistamaan toisensa yksilöllisesti ja muistavat oman asemansa lauman hierarkiassa suhteessa muiden laumanjäsenten asemaan (Fraser ja Broom 2002). Nautojen on esitetty pystyvän tunnistamaan yksilöllisesti 50-70 lajitoveriaan.

Kondo ym. (1989) tutkivat ryhmäkoon (8-91 eläintä) vaikutusta yli kaksivuotiailla hiehoilla, lehmillä ja härillä ja havaitsivat aggressioiden lisääntyvän ryhmäkoon kasvaessa. Phillipsin (1993) mukaan aggressiot lisääntyvät, koska ryhmän suurentuessa lajitoverien sosiaalisen aseman muistaminen vaikeutuu. Kun suuria eläinmääriä laidunnetaan laajoilla alueilla, naudoilla on kuitenkin taipumus muodostaa pienempiä, noin 10-15 eläimen alaryhmiä (Hinch ym. 1982, Phillips 1993). Alaryhmiä muodostamalla naudat pyrkivät vähentämään suuresta ryhmästä johtuvia haittoja (Phillips 1993).

\section{Ryhmäkoon vaikutus terveyteen}

Ryhmäkoon kasvun (100-400 eläintä) on todettu lisäävän härillä buller steer -syndroomaa feedlotkasvattamoissa (Acosta ym. 1981). Buller steer -syndrooma ilmenee siten, että buller-härät sallivat muiden härkien toistuvasti hyppiä selkäänsä. Tästä seuraa buller-härkien uupuminen, loukkaantuminen, kasvun heikkeneminen ja jopa kuolema. Acosta ym. (1981) arvelivat syndrooman yleistymisen johtuvan eläinten välisten sosiaalisten suhteiden muuttumisesta monimutkaisemmiksi ryhmäkoon kasvaessa.

\section{Eläintiheyden vaikutus tuotantoon}

Tutkimustulosten yleinen suuntaus on, että eläintiheyden kasvaminen ts. eläintä kohden varatun karsinatilan pieneneminen, vaikuttaa negatiivisesti lihanautojen kasvuun, rehunkulutukseen ja rehuhyötysuhteeseen. Ruhon tai lihan laatuun eläintiheydellä ei kuitenkaan näyttäisi olevan vaikutusta.

Hickeyn ym. (2003) tutkimuksessa härkien (alkupaino $520 \mathrm{~kg}$ ) nettokasvu, rehunkulutus ja rehuhyötysuhde heikkenivät, kun tilaa oli eläintä kohden 1,5 tai 2,0 m²/eläin kuin 3,0 tai 4,0 m²/eläin. Ruhon lihakkuuteen tai rasvaisuuteen eläintiheydellä ei ollut vaikutusta. Ruis-Heutinckin ym. (2000) tutkimuksessa sonnit (alkupaino $220 \mathrm{~kg}$ ) söivät enemmän ja kasvoivat paremmin alhaisemmassa eläintiheydessä (4,2 $\mathrm{m}^{2} /$ eläin) kuin korkeammassa eläintiheydessä (2,0 m²/eläin). Andersenin ym. (1997) kokeessa tilaa oli sonnia kohden $1,4,1,7$ tai $2,5 \mathrm{~m}^{2} 100-300 \mathrm{~kg}: n$ painoisina ja tästä eteenpäin teurastukseen (460 kg:n painoisiksi) tilaa oli vastaavasti 1,8, 2,2 tai 3,1 $\mathrm{m}^{2} / \mathrm{eläin}$. Sonnien kasvu ja rehuhyötysuhde heikkenivät eläintiheyden kasvaessa. Rehunkulutukseen ja ruhon tai lihan laatuun eläintiheydellä ei ollut vaikutusta. Hickey ym. (2002) tutkivat eläintiheyden vaikutusta härkien (alkupaino $470 \mathrm{~kg})$ tuotantoon hakepohjaisissa ulkoaitauksissa. Aitauksen eläintiheydellä $(6,12$ tai 18 m²/eläin) ei ollut vaikutusta härkien kasvuun, rehunkulutukseen tai rehuhyötysuhteeseen.

Fisherin ym. (1997a) tutkimuksessa hiehot (alkupaino $470 \mathrm{~kg}$ ) kasvoivat heikommin, märehtivät vähemmän ja niiden teurasprosentti oli suurempi korkeassa eläintiheydessä $\left(1,5 \mathrm{~m}^{2} / \mathrm{eläin}\right)$ kuin alhaisemmissa eläintiheyksissä (2,0, 2,5 tai 3,0 m²/eläin). Samoin Fisherin ym. (1997b) toisessa kokeessa hiehot (alkupaino $470 \mathrm{~kg}$ ) kasvoivat heikommin ja niiden teurasprosentti oli suurempi korkeammassa eläintiheydessä $\left(1,5 \mathrm{~m}^{2} / \mathrm{eläin}\right)$ kuin alhaisemmassa eläintiheydessä $\left(3,0 \mathrm{~m}^{2} / \mathrm{eläin}\right)$. Hindheden ym. (1996) kokeessa eläintiheydellä ei ollut vaikutusta hiehojen (alkupaino $300 \mathrm{~kg}$ ) rehunkulutukseen, mutta alhaisemmassa eläintiheydessä $\left(3,0 \mathrm{~m}^{2} /\right.$ eläin) hiehojen kasvu ja rehuhyötysuhde olivat parempia kuin korkeammassa eläintiheydessä (1,5 m²/eläin). Mogensenin ym. (1997) kokeessa hiehot kasvoivat sitä paremmin ja söivät sitä enemmän mitä suurempi karsinatila $\left(3,6,4,5\right.$ tai $5,5 \mathrm{~m}^{2} /$ eläin) niillä oli käytettävissään. Rehuhyötysuhteeseen eläintiheydellä ei ollut vaikutusta.

Ingvartsen ja Andersen (1993) esittivät tuotannon heikkenemisen olevan "biologinen kustannus" sopeutumisesta ahtauden aiheuttamaan sosiaaliseen stressiin. Heidän mukaansa ahtaudesta johtuva stressi voi muuttaa hormonien eritystä ja siten aiheuttaa ruokahalun heikkenemistä. Oloissa, joissa tilanpuutteen vuoksi nautojen makuukäyttäytyminen on häiriintynyt, eläimillä on havaittu lisääntynyttä seisomista tai märehtimisen vähentymistä (Fisher ym. 1997a). Seisomisesta johtuvien energiakustannusten tai märehtimisen vähentymisen on esitetty voivan olla syynä heikentyneeseen rehuhyötysuhteeseen. Ingvartsen ja Andersen (1993) muodostivat useiden aiemmin tehtyjen kasvatuskokeiden perusteella matemaattisia käyriä lihanautojen kasvulle, rehunkulutukselle ja rehuhyötysuhteelle. Käyrien perusteella he päättelivät, että 250-500 kg:n painoisten sonnien ja härkien kasvu, rehunkulutus ja rehuhyötysuhde ovat optimaalisia, kun tilaa eläintä kohden on vähintään $4,7 \mathrm{~m}^{2}$. 


\section{Eläintiheyden vaikutus käyttäytymiseen}

\section{Makuukäyttäytyminen}

Korkeassa eläintiheydessä ryhmän kaikkien jäsenten on vaikeaa tai mahdotonta asettua makuulle samanaikaisesti. Tästä seuraa makuulla vietetyn ajan vähentyminen (Fisher ym. 1997a, Hickey ym. 2003, Jensen ym. 1995). Hickeyn ym. (2003) tutkimuksessa härät (520 kg) makasivat vuorokaudessa noin kaksi tuntia vähemmän korkeassa eläintiheydessä ( $\left.1,5 \mathrm{~m}^{2} / \mathrm{eläin}\right)$ kuin alhaisemmissa eläintiheyksissä (2,0, 3,0 tai 4,0 $\mathrm{m}^{2} / \mathrm{eläin).} \mathrm{Makuutilan} \mathrm{vähäisyys} \mathrm{johtaa} \mathrm{makuukäyttäytymisen} \mathrm{synkronisuuden}$ vähentymiseen (Mogensen ym. 1997, Nielsen ym. 1997) ja voi myös lisätä toisen eläimen puskemista ja pakottamista ylös (Nielsen ym. 1997). Nielsen ym. (1997) ja Mogensen ym. (1997) havaitsivat, että $1,8 \mathrm{~m}^{2}$ kuivitettua makuualuetta eläintä kohden on riittämätön, jotta $400 \mathrm{~kg}: \mathrm{n}$ painoiset hiehot mahtuisivat makaamaan alueelle samaan aikaan.

Liukkaalla ja kovalla rakolattialla vaikeudet asettua makuulle ja nousta ylös luonnolliseen tapaan ovat yleisiä (Graf 1979, Ruis-Heutinck ym. 2000). Epänormaalit makuulleasettumiset ja ylösnousut yleistyvät eläinten kasvaessa ja karsinatilan pienentyessä Graf (1979). Ruis-Heutinckin ym. (2000) tutkimuksessa sonnit suorittivat korkeassa eläintiheydessä (2,0 m²/eläin) makuulleasettumisista 89,6 \% ja ylösnousuista $87,1 \%$ epänormaalisti. Alhaisemmassa eläintiheydessä $\left(4,2 \mathrm{~m}^{2} /\right.$ eläin) epänormaaleja liikkeitä esiintyi vähemmän, mutta kuitenkin huomattavasti: makuulleasettumisista 69,7 \% ja ylösnousuista $71,8 \%$ suoritettiin epänormaalisti.

\section{Sosiaalinen, epänormaali ja leikkikäyttäytyminen}

Eläintiheyden kasvun on todettu lisäävän eläinten välistä agonistista käyttäytymistä (uhkailu, puskeminen, alistuminen) hiehoilla ja härillä (Kondo ym. 1989) ja aggressioita sonneilla (Wierenga 1987). Lehmillä on havaittu agonistista käyttäytymistä vähemmän laitumella kuin sisällä pihatossa (O’Connell ym. 1989, Miller ja Wood-Gush 1991). Aggressioiden lisääntymisen eläintiheyden kasvaessa on esitetty johtuvan lisääntyvistä yksilötilan loukkauksista, koska ahtaudessa eläinten on vaikeampi väistää toisiaan (Wierenga 1983). Myös mieluisiin alueisiin kuten ruokailutilaan tai makuupaikkaan kohdistuva kilpailu voi lisätä aggressioita.

Eläintiheydellä ei ole havaittu vaikutusta härkien stereotyyppisen käyttäytymisen määrään (Hickey ym. 2003) tai hiehojen epänormaalin oraalisen käyttäytymisen määrään (Fisher ym. 1997b). Wierenga (1987) havaitsi sonneilla enemmän esineiden manipulointia korkeassa eläintiheydessä $(1,95$ $\mathrm{m}^{2} /$ eläin) kuin alhaisemmassa eläintiheydessä (2,60 $\left.\mathrm{m}^{2} / \mathrm{eläin}\right)$. Eläintiheyden kasvamisen (Fisher ym. 1997b) ja kuivitetun makuualueen vähenemisen (Nielsen ym. 1997) on kuitenkin todettu lisäävän ns. nojailukäyttäytymistä (leaning). Nojatessaan nauta painaa päätään tai turpaansa yhtäjaksoisesti useiden minuuttien ajan rakenteita tai toista eläintä vasten. Pään nojailun on esitetty olevan epänormaalia, uudelleen suuntautunutta käyttäytymistä (Wiepkema ym. 1983).

Jensen ym. (1998) tutkivat eläintiheyden vaikutusta 2, 4 ja 6 viikon ikäisten hiehovasikoiden käyttäytymiseen oljella kuivitetuissa ryhmäkarsinoissa. Neljän ja kuuden viikon ikäisinä vasikat leikkivät vähemmän pienemmässä karsinassa (1,4 m²/eläin) kuin suuremmassa karsinassa (4,1 $\left.\mathrm{m}^{2} / \mathrm{eläin}\right)$.

\section{Eläintiheyden vaikutus terveyteen}

\section{Stressifysiologia ja immunologia}

Kroonisen stressin vaikutuksesta stressihormonien, kuten kortisolin eritys voi lisääntyä. Kortisolieritystä voidaan tutkia injektoimalla eläimeen synteettistä kortikotropiinihormonia (ACTH), joka stimuloi lisämunuaiskuoren erittämään maksimaalisen annoksen kortisolia (Broom ja Johnson 1993). Naudoilla on havaittu alentunut tai puuttuva lisämunuaisen vaste ACTH-injektiolle korkeassa eläintiheydessä verrattuna alhaisempaan eläintiheyteen (Ladewig ym. 1985, Fisher ym. 1997a, 1997b). Kroonisen stressin seurauksena lisämunuaiskuoren ACTH-reseptorien määrää saattaa vähentyä (vaimennussäätely, down regulation, Greco ja Ftabenfeldt 2002), mikä voi olla selityksenä myös nautojen alentuneelle tai puuttuvalle vasteelle ACTH-injektioon korkeassa eläintiheydessä.

Stressi voi heikentää eläimen immuunijärjestelmän toimintaa ja vaikuttaa valkosolujen määrään ja veren koostumukseen (Broom ja Johnson 1993). Useimmissa kokeissa eläintiheydellä ei ole havaittu vaikutusta lihanautojen immuunijärjestelmän toimintaan tai veren ominaisuuksiin (Fisher ym. 
1997a, 1997b, Hickey ym. 2002). Hickeyn ym. (2003) kokeessa härkien $\gamma$-interferonin in vitro tuotanto heikkeni eläintiheyden kasvaessa $\left(1,5,2,0,3,0\right.$ tai 4,0 $\mathrm{m}^{2}$ /eläin) vierasta antigeeniä ja Concanavalin A-käsittelyä kohtaan. Eläintiheydellä ei kuitenkaan ollut vaikutusta veren valkosolujen, punasolujen, verihiutaleiden, hemoglobiinin, haptoglobiinin tai fibrinogeenin pitoisuuksiin.

\section{Muu terveys}

Korkea eläintiheys altistaa nautoja tarttuville taudeille, kuten hengitystietulehduksille (Härtel 1999) Suuressa eläintiheydessä eläinten väliset kontaktit lisääntyvät ja tartunnan leviäminen eläinten välillä helpottuu (Rosengren ym. 2000). Ahtaassa karsinassa sonnien on havaittu kävelevän toistensa yli ja tallovan toisiaan useammin kuin tilavammassa karsinassa (Lidfors 1992). Makaavan eläimen hännän jäädessä toisen eläimen sorkan alle häntä voi ruhjoutua ja sen seurauksena tulehtua vakavasti. Häntien vauriot ovat ongelma lähinnä rakolattiapohjaisissa karsinoissa (Madsen 1987, Drolia ym. 1990). Monissa tutkimuksissa häntäpolkemien on todettu lisääntyvän ja muuttuvan vakavammiksi eläintiheyden kasvaessa (Madsen ym. 1987, Andersen ym. 1997, Schrader 2001).

\section{Eläintiheyden vaikutus eläinten puhtauteen}

Tilatutkimuksessaan Kirkland ja Steen (2001) havaitsivat pohjoisirlantilaisilla tiloilla lihanautojen olevan sitä likaisempia mitä korkeammassa eläintiheydessä eläimiä pidettiin. Tutkimuksessa oli mukana sekä rakolattiakarsinoita että olkikuivitukselle perustuvia kasvatusmuotoja. Myös koeoloissa nautojen on todettu olevan sitä likaisempia mitä korkeammassa eläintiheydessä niitä kasvatetaan (Andersen ym. 1997, Hickey ym. 2002, Hickey ym. 2003). Näistä tutkimuksista poiketen Fisher ym. (1997b) ja Hindhede ym. (1996) eivät havainneet eläintiheydellä (1,5 tai 3,0 m²/eläin) vaikutusta rakolattialla kasvaneiden hiehojen puhtauteen.

\section{Yhteenveto ja johtopäätökset}

\section{Ryhmäkoko}

Tutkimusten perusteella suhteellisen pieni ryhmäkoko (noin 5-20 eläintä) on turvallinen valinta nautojen tuotantoa ajatellen. Nautojen kasvu saattaa heiketä ryhmäkoon suurentuessa (20-60 eläintä), mutta suurien ryhmäkokojen osalta kaivataan lisätutkimuksia. Nautojen sosiaalisen käyttäytymisen perusteella pieni ryhmäkoko on suurta suositeltavampi. Eläinten on helpompi tunnistaa toisensa yksilöllisesti ja muistaa oma hierarkkinen asemansa suhteessa muiden laumanjäsenten asemaan pienessä kuin suuremmassa ryhmässä. Ryhmäkoon ylärajana voidaan pitää 50-70 eläintä, jonka ylittyessä naudan kyky tunnistaa toisia yksilöitä heikkenee. Jos lihanautoja pidetään suurissa ryhmissä, tilaa on oltava runsaasti, jotta eläimet voivat halutessaan muodostaa pienempiä alaryhmiä.

\section{Eläintiheys}

Tutkimusten perusteella eläintiheyden kasvaessa lihanautojen kasvu, rehunkulutus ja rehuhyötysuhde heikkenevät, mutta eläintiheydellä ei ole havaittu vaikutusta ruhon tai lihan laatuun. Eläintiheyden kasvu heikentää lihanautojen terveyttä lisäämällä hantäpolkemia. Lisäksi lisämunuaisten toiminta voi muuttua, minkä voidaan katsoa johtuvan kroonisesta stressistä. Eläintiheyden kasvaessa lihanaudat myös likaantuvat herkemmin.

Eläintiheyden kasvulla on monia negatiivisia vaikutuksia lihanautojen käyttäytymiseen. Karsinatilan pienentyessä vasikoiden leikkikäyttäytyminen vähenee. Makuutilan vähentyessä ryhmän makuukäyttäytyminen muuttuu epäsynkronisemmaksi ja makaavien eläinten häirintä voi lisääntyä. Hyvin korkeassa eläintiheydessä eläinten makuulla viettämä aika vähenee. Eläintiheyden kasvaessa nojailukäyttäytyminen voi lisääntyä. Rakolattialla karsinan ahtaus vaikeuttaa makuulle asettumista ja ylösnousua, minkä vuoksi epänormaalisti suoritetut liikkeet lisääntyvät. Korkeassa eläintiheydessä eläimillä voi olla vaikeuksia haluamansa yksilötilan säilyttämisessä tai dominoivan lajikumppanin väistämisessä, mikä lisää eläinten välisiä aggressioita.

Tutkimustuloksiin perustuen Suomen eläinsuojelusäädöksissä esitetyt ryhmäkasvatettavien nautojen minimitilavaatimukset (Taulukko 1) ja -suositukset (Taulukko 2) ovat lihanautojen kasvatuksessa ehdoton eläintiheysminimi. Jotta naudoilla olisi mahdollisuus toteuttaa paremmin lajintyypillistä käyttäytymistään, tilaa eläintä kohden tulisi olla vaatimuksia ja suosituksiakin enemmän. Etenkin rakolattiakasvatuksessa lisätila parantaisi eläinten terveyttä ja voisi vaikuttaa myönteisesti myös eläinten 
kasvuun. Suosituksissa kaikille yli $500 \mathrm{~kg}$ :n painoisille lihanaudoille on annettu sama minimitila, mutta on selvää, että yli $600 \mathrm{~kg}: n$ painoinen eläin tarvitsee enemmän tilaa kuin $500 \mathrm{~kg}: n$ painoinen eläin. Siten varsinkin kasvatuksen loppuvaiheessa naudoilla tulisi olla käytössään vähimmäistilasuosituksiakin suurempi karsinatila. Näitä johtopäätöksiä tukevat myös Euroopan komission suositukset, joiden mukaan tilaa tulisi varata vähintään $3 \mathrm{~m}^{2} / \mathrm{eläin} 500 \mathrm{~kg}$ :n painoiseksi kasvavalle naudalle ja vieläkin enemmän tätä suuremmille eläimille (European Commission 2001).

\section{Kirjallisuus}

Acosta, J. E., Shake, L. M., Brown, G. C. \& Vermedahl, L. D. 1981. Influence of implants, feed additives and pen size upon incidence of buller steers. Progress Report Texas Agricultural Experiment Station 3758/3830: 130133.

Andersen, H. R., Jensen, L. R., Munksgaard, L. \& Ingvartsen, K. L. 1997. Influence of floor space allowance and access sites to feed trough on the production of calves and young bulls and on the carcass and meat quality of young bulls. Acta Agric. Scand., Sect. A, Animal Sci. 47: 48-56.

Broom, D. M. \& Johnson, K. G. 1993. Stress and animal welfare. Lontoo: Chapman \& Hall. 211 s. ISBN 0412-39580-0.

Drolia, H., Luescher, U. A. \& Meek, A. H. 1990. Tail-tip necrosis in Ontario feedlot cattle: two case-control studies. Prev. Vet. Med. 9: 195-205.

European Commission. 2001. The welfare of cattle kept for beef production. Scientific Committee on Animal Health and Animal Welfare. Saatavissa internetistä: http://europa.eu.int/comm/food/fs/sc/scah/out54_en.pdf

Fisher, A. D., Crowe, M. A., O’Kiely, P. \& Enright, W. J. 1997a. Growth, behaviour, adrenal and immune responses of finishing beef heifers housed on slatted floors at 1.5, 2.0, 2.5 or $3.0 \mathrm{~m}^{2}$ space allowance. Livest. Prod. Sci. 51: 245-254.

Fisher, A. D., Crowe, M. A., Prendiville, D. J. \& Enright, W. J. 1997b. Indoor space allowance: effects on growth, behaviour, adrenal and immune responses of finishing beef heifers. Anim. Sci. 64: 53-62.

Fraser, A. F. \& Broom, D. M. 2002. Farm animal behaviour and welfare. Kolmas painos. Oxon: CABI Publishing. $437 \mathrm{~s}$.

Graf, B. 1979. Spaltenbodenhaltung bei Mastochsen. Landbauforschung Völkenrode Sonderheft 48: 73-88.

Greco, D. \& G. H. Ftabenfeldt, G. H. 2002. The endocrine system. Teoksessa: Cunningham, J. G. (toim.). Textbook of veterinary physiology. Kolmas painos. Philadelphia: W.B. Saunders Company. s. 324-340.

Hafez, E. S. E. \& Bouissou, M. F. 1975. The behaviour of cattle. Teoksessa: Hafez, E. S. E. (toim.), The behaviour of domestic animals. London: Bailliére Tindall. s. 203-237. ISBN 0-7020-0549-5.

Hickey, M. C., Earley, B. \& Fisher, A. D. 2003. The effect of floor type and space allowance on welfare indicators of finishing steers. Irish J. Agric. and Food Res. 42: 89-100.

Hickey, M.C., French, P. \& Grant, J. 2002. Out-wintering pads for finishing beef cattle: animal production and welfare. Anim. Sci. 75: 447-458.

Hinch, G. N., Thwaites, C. J., Lynch, J. J. \& Pearson, A. J. 1982. Spatial relationships within a herd of young sterile bulls and steers. Appl. Anim. Ethol. 8: 27-44.

Hindhede, J., Sørensen, J. T., Jensen, M. B. \& Krohn C. C. 1996. Effect of space allowance, access to bedding, and flock size in slatted floor systems on the production and health of dairy heifers. Acta Agric. Scand., Sect. A, Animal Sci. 46: 46-53.

Hristov, V. 1974. Calf fattening as affected by group size. I announcement. Anim. Sci. 3: 16.

Härtel, H. 1999. Vasikoiden ja nuorten nautojen hengitystiesairaudet. Helsinki. 68 s.

Ingvartsen, K. L. \& Andersen, H. R. 1993. Space allowance and type of housing for growing cattle. A review of performance and possible relation to neuroendocrine function. Acta Agric. Scand., Sect. A, Animal Sci. 43: 65-80.

Jensen, M. B., Krohn, C. C., Hindhede, J. \& Sørensen, J. T. 1995. Resting behaviour of heifers housed in pens with slatted floor, the effect of space allowance and access to a bedded lying area. Proceedings of the $29^{\text {th }}$ International Congress of the International Society for Applied Ethology, 3-5 August 1995, Exeter, UK. s. 183184.

Jensen, M. B., Vestergaard, K. S. \& Krohn, C. C. 1998. Play behaviour in dairy calves kept in pens: the effect of social contact and space allowance. Appl. Anim. Behav. Sci. 56: 97-108.

Kirkland, R. M. \& Steen, R. W. J. 2001. Studies on the effects of housing system on the behaviour, welfare and performance of beef cattle and on factors affecting the cleanliness of housed cattle. Annual Report Agricultural Research Institute of Northern Ireland, 2000-2001. s. 30-39.

Kondo, S., Sekine, J., Okubo, M. \& Asahida, Y. 1989. The effect of group size and space allowance on the agonistic and spacing behavior of cattle. Appl. Anim. Behav. Sci. 24: 127-135. 
Ladewig, J., Schlichting, M. C., Beneke, B., Borell, E. von, Stuhec, I. \& Smidt, D. 1985. Physiological aspects of social space in heifers and pigs. Teoksessa: Zayan, R. (toim.), Social space for domestic animals. Netherlands: Martinus Nijhoff. s. 151-159.

Lidfors, L. 1992. Behaviour of bull calves in two different housing systems: Deep litter in an uninsulated building versus slatted floor in an insulated building. Report -Institutionen för husdjurshygien. No. 30. Skara: Sveriges Lantbruksuniversitet. $108 \mathrm{~s}$.

MacNeil, M. D., Gregory, K. E. \& Ford, J. J. 1989. Management of yearling bulls in a feedlot. Journal of Anim.al Sci. 67: 858-864.

Madsen, E. B. 1987. Tail tip inflammation in young fattening bulls on slatted floors. Teoksessa: Schlichting, M. C. \& Smidt, D. (toim.), Welfare aspects of housing systems for veal calves and fattening bulls. s. 131-138.

Madsen, E. B., Thysen, I., Ingvartsen, K. L. \& Østergaard, V. 1987. Ungtyres sundhed og produktion ved forskellig belægning i spaltegulvsbokse. Beretn. nr. 628, Statens Husdyrbrugsforsøg, Foulum. s 209-218.

Miller, K. \& Wood-Gush, D. G. M. 1991. Some effects of housing on the social behaviour of dairy cows. Anim. Prod. 53: 271-278.

MMMA 7.6.1996/396. Eläinsuojeluasetus. Annettu Helsingissä 7.6.1996. Suomen säädöskokoelma 396/1996: 1019-1028.

MMMA 3.6.2002/6/EEO/2002. Maa- ja metsätalousministeriön asetus Nautojen pidolle asetettavista eläinsuojeluvaatimuksista annetun Maa- ja metsätalousministeriön päätöksen muuttaminen. Annettu Helsingissä 3.6.2002. Päivitetty: 6/2002. Viitattu: 30.11.2005. Saatavissa internetistä: http://www.mmm.fi/el/laki/F/f20m1 fi.pdf

MMMp 23.5.1997/14/EEO/1997. Maa- ja metsätalousministeriön päätös F20 Nautojen pidolle asetettavat eläinsuojeluvaatimukset. Annettu Helsingissä. Viitattu: 30.11.2005. Saatavissa internetistä: http://www.mmm.fi/el/laki/F/f20.html

Mogensen, L., Nielsen, L. H., Hindhede, J., Sørensen, J. T. \& Krohn, C. C. 1997. Effect of space allowance in deep bedding systems on resting behaviour, production, and health of dairy heifers. Acta Agric. Scand., Sect. A, Animal Sci. 47: 178-186.

Neumann, W., Scheibe, G. \& Hennings, J. 1974. Ergebnisse über Wechselbeziehungen zwischen Umwelt Verhalten - Leistung in der industriemäßigen Jungrindermast. Tierzucht 28: 132-134.

Nielsen, L. H., Mogensen, L., Krohn, C., Hindhede, J. \& Sørensen, J. T. 1997. Resting and social behaviour of dairy heifers housed in slatted floor pens with different sized bedded lying areas. Appl. Anim. Behav. Sci. 54: 307-316.

O’Connell, J., Giller, P. S. \& Meaney, W. 1989. A comparison of dairy cattle behavioural patterns at pasture and during confinement. Irish J. Agric. Res. 28: 65-72.

Phillips, C. J. C. 1993. Cattle behaviour. United Kingdom: Farming press. 212 s.

Plyaschenko, S. I. \& Yakovlev, L. A. 1987. Optional group size in fattening of bulls. Zhivotnovodstvo 8: 4950.

Rosengren, H., Katainen, A. \& Heinola, T. 2000. Tuotantoeläinten tarttuvat taudit ja tuotantoympäristön rakenteelliset ja toiminnalliset ratkaisut. Kotieläinhygienian julkaisuja 23. Helsinki: Helsingin yliopisto, Eläinlääketieteellinen tiedekunta, Kliinisen eläinlääketieteen laitos.

Ruis-Heutinck, L. F. M., Smits, M. C. J., Smits, A. C. \& Heeres, J. J. 2000. Effects of floor type and floor area on behaviour and carpal joint lesions in beef bulls. Improving health and welfare in animal production: Proceedings of sessions of the EAAP Commission on animal management and health, the Hague, the Netherlands, 21-24 August 2000. s. 29-36

Schlichting, M. von, Smidt, D. \& Müller, C. 1990. Aspekte zur tiergerechten Aufstallung von Mastkälbern in Gruppen. Tierärztl. Umschau 45: 785-791.

Schrader, L., Roth, H-R., Winterling, C., Brodmann, N., Langhans, W., Geyer, H. \& Graf, B. 2001. The occurrence of tail tip alterations in fattening bulls kept under different husbandry conditions. Animal Welfare 10: 119-130.

Wiepkema, P. R., Broom, D. M., Duncan, I. J. H. \& van Putten, G. 1983. Abnormal behaviours in farm animals. A report of the Commission of the European Communities. $16 \mathrm{~s}$.

Wierenga, H. K. 1983. The influence of the space for walking and lying in a cubicle system on the behaviour of dairy cattle. Teoksessa: Baxter, S. H., Baxter, M. R. \& MacCormack, J. A. D. (toim.), Farm animal housing and welfare. Seminar in the CEC Programme of Coordination of Research on Animal Welfare, Aberdeen, Scotland, July 28-30, 1982. Martinus Nijhoff: The Hague, Netherlands. s. 171-180

Wierenga, H. K. 1987. Behavioural problems in fattening bulls. Teoksessa: Schlichting, M. C. \& Smidt, D. (toim.), Welfare aspects of housing systems for veal calves and fattening bulls. s. 105-122. 